\title{
Response of organic manures to the growth of onion cultivars in Peshawar valley
}

\author{
Murad Ali ${ }^{1}$, Gohar Ayub ${ }^{1}$, Nangial Khan ${ }^{2,3 *}$, Mohammad Wasiullah \\ Khan $^{1}$, Ahmad Naeem ${ }^{1}$, Kabir Khan ${ }^{3}$, Shahid Rehman ${ }^{1}$, Muhammad \\ Afzaal $^{4}$, Maazur Rehman ${ }^{1}$ and Rafi Ullah ${ }^{1}$ \\ 1. Department of Horticulture, The University of Agriculture, Peshawar-Pakistan \\ 2. State Key Laboratory of Cotton Biology, Institute of Cotton Research, Chinese Academy of Agricultural \\ Sciences, Anyang, Henan-China \\ 3. Department of Agronomy, The University of Agriculture, Peshawar-Pakistan \\ 4. Department of Entomology, The University of Agriculture, Peshawar-Pakistan \\ *Corresponding author's email: nangialkhan@aup.edu.pk \\ Citation
}

Murad Ali, GoharAyub, Nangial Khan, Mohammad Wasiullah Khan, Ahmad Naeem, Kabir Khan, Shahid Rehman, Muhammad Afzaal, Maazur Rehman and Rafi Ullah. Response of organic manures to the growth of onion cultivars in Peshawar valley. Pure and Applied Biology. Vol. 8, Issue 2, pp1374-1384. http://dx.doi.org/10.19045/bspab.2019.80078

\begin{tabular}{llll}
\hline \hline Received: 02/01/2019 & Revised: 11/04/2019 & Accepted: 14/04/2019 & Online First: 04/05/2019 \\
\hline \hline
\end{tabular}

\section{Abstract}

An experiment was carried out to investigate the "Effect of organic manures on the growth of onion cultivars at Peshawar valley" at the Horticulture Research Farm, The University of Agriculture Peshawar, during 2014-2015. The experimental design was Randomized Complete Block Design with split plot arrangement and having three replications. The experiment was consisted of two factors i.e. the organic manures Farmyard manure (FYM), Poultry manure (PM), Spent mushroom compost (SMC), 1/2FYM + $1 / 2 \mathrm{PM}, 1 / 2 \mathrm{FYM}+1 / 2 \mathrm{SMC}, 1 / 2 \mathrm{PM}+1 / 2 \mathrm{SMC}$ and $1 / 3 \mathrm{FYM}+1 / 3 \mathrm{PM}+1 / 3 \mathrm{SMC}$ were subjected to main plot at the rate of 10 tons ha ${ }^{-1}$ and onion cultivars (Parachinar-Local, Swat-1 and Swat-Local) were maintained to the sub plot. The onion growth was significantly affected by both organic manures application and onion cultivars. The application of organic manure (poultry manure) significantly improved the survival percentage $(85.9 \%)$, number of leaves plant ${ }^{-1}(16.1)$, leaf length $(47.6 \mathrm{~cm})$,neck height $(7.6 \mathrm{~cm})$, plant height $(79.3 \mathrm{~cm})$ and leaf width $(1.3 \mathrm{~cm})$. The organic manures alone and organic manures combination showed different variation in growth of onion crop. In case of onion cultivars, Parachinar-Local cultivar increased significantly the survival percentage $(81.8 \%)$, number of leaves per plant $(12.0)$, leaf length $(40.1 \mathrm{~cm})$, leaf width $(1.06 \mathrm{~cm})$, neck height $(6.0 \mathrm{~cm})$ and plant height $(69.5 \mathrm{~cm})$. The interaction of organic manure (poultry manure) and onion cultivar (Parachinar-Local) also effected the growth of onion. In case of interaction the organic manure (poultry manure) @ 10 tons $\mathrm{ha}^{-1}$ with onion cultivar (Parachinar-Local) suited for the growth of onion crop. Fromresults it is concluded that the onion cultivar (Parachinar-Local) received organic manure (poultry manure) @ 10 tons ha $^{-1}$ showed best result in growth at agro-climatic condition of Peshawar Khyber Pakhtunkhwa-Pakistan.

Keywords: Cultivars; Farm yard manure; Growth; Onion; Poultry manure; Spent mushroom compost 


\section{Introduction}

Onion (Allium cepa L.) is one of the important vegetable crops, belongs to family Amaryllidaceae and sub family Allioideae. It is cultivated in the world widely especially in Asia. Onion is grown in Pakistan as commercially vegetable crop. The onion (Allium cepa L.) is used on daily basis as a condiment either as mature bulb in salad and also for preparation of other different dishes or as green leaves [1]

Onion is cool season crop and it is also biennial, cross pollinated crop mostly and shallow rooted crop. The onion produced wide range of bulbs depending on the varieties. The bulbs having various sizes such as small, medium and large and also having different colors i.e. white, yellow and red and also different shapes such as flattened, round and globular. The onion is categorized in short days and long days which is dependent on day length requirement. [2]. The pungency in the bulb is presence due to the volatile oil (allyl propyl disulphide) [3].

Onion is grown on different types of soil but they grown best on fertile soil which contain humus and also well drained. In high acidity condition it is very sensitive and produces more yield with optimum $\mathrm{pH}$ range (5.8-6.5). It is grown in other types of soil also such as clay, sandy loams and mucks. Onion seedlings are transplanted to the field by keeping the row to row distance $(30 \mathrm{~cm}$ and plant to plant distance $(15 \mathrm{~cm})$.

In Khyber Pakhtunkhwa the onion total average yield is (16.6) tons per hectare and area of cultivation in KP is (11.1) hectare with a production of (187.5) tons[4].

Onion is a high valued cash crop next to chili due to high cost of production. Presently it price are high and consumers cannot affordable it and there are so many problems in marketing to the farmers and they do not have better profits from its cultivation. Another reason is that farmers also paid more prices for buying fertilizers. Normally excessive amount of chemical fertilizers are applied to vegetables crops for more production [5]. Whenever chemical fertilizers applied to soil it produce several harmful effects to human health and also to environmental condition [6]. Soil structure affected by more usage of inorganic fertilizers, therefore organic manures used as alternative to chemical fertilizers for improving soil structure [7]. The organically and inorganically fertilized plants were both had higher uptakes of $\mathrm{N}, \mathrm{P}$ and $\mathrm{K}$ then unfertilized plants [8].

Organic manures i.e. Spent mushroom compost which contains materials such as humus, essentials Nutrients in different amounts i.e. Nitrogen $0.7 \%$, phosphorus $0.3 \%$ and potassium $0.3 \%$. By adding spent mushroom compost increase the $\mathrm{pH}$ of soil because it is alkaline in nature due to presence of chalk content [9].The nutrients are very important for the production and quality of onion and by continuous use of inorganic fertilizers many problems produced that are scarcity of micronutrients, imbalance in soil physical and chemical properties and unsustainable crop production. By this reason the farmers started organic farming systems in which no use of synthetic fertilizers and pesticides [10].

Organic manures enhance the different properties of soil i.e. physical, chemical and biological and also increase the moisture holding capacity of soil which resulted more in maintaining the quality of crop production and crop production [11]. The organic fertilizers hold plant nutrients which promote enzymes and hormones, besides plant nutrients make them necessary for enhancement of soil fertility and production [12]. Before using organic manures we should want to check it by different ways. To avoid using fresh manure of animals that contains different pathogens this harmful to plants. To kill pathogens that present in compost manure and to applied the manure in 
best time to avoid excessive leaching and runoff [13].

Organic manure and bio fertilizers mixture increased the yield and provide more nutrients to onion tuber [14]. The growers got more profit by organic farming system. In organic farming less cost of production required and it is reduce the chance of environmental pollution. It is also improved the soil structure, enhance different activities of soil organisms which are useful to plants. The vegetables and fruits etc produced by organic farming are good for human health [15].

Keeping the above points in view the research study was conducted at Horticulture Research Farm, The University of Agriculture Peshawar, to know the importance of different organic manures on onion cultivars.

\section{Materials and methods}

An experiment was conducted to study "Effect of organic manures on the growth of onion cultivars at Peshawar valley" at Horticulture Research Farm, The University of Agriculture Peshawar, to find out the optimum source of organic manure for the better growth of onion cultivars.

\section{Preparation of organic media}

For the preparation of organic media the organic materials were collected from different centers such as poultry manure from poultry farm, spent mushroom compost from mushroom research centre and farmyard manure from Diary Farm situated in the University of Agriculture Peshawar. Seven different media were prepared, firstly prepared three media of farmyard manure (FYM), poultry manure (PM) and spent mushroom compost (SMC) alone at the rate of 10 tons ha- $\mathrm{h}^{-1}$. The four different mixtures of organic media were also made at the rate of 10 tons ha $^{-1}$ i.e. $1 / 2 \mathrm{FYM}+1 / 2 \mathrm{PM}, 1 / 2 \mathrm{FYM}+$ $1 / 2 \mathrm{SMC}, 1 / 2 \mathrm{PM}+1 / 2 \mathrm{SMC}$ and $1 / 3 \mathrm{FYM}+1 / 3 \mathrm{PM}$ $+{ }^{1 / 3}$ SMC. The organic manures were applied the field about one month before the transplantation of onion seedlings.

The organic manures were mixed in the soil of the plot of field. The recommended level of NPK i.e. half level of nitrogen at rate of $\left(60 \mathrm{~kg} \mathrm{ha}^{-1}\right)$, phosphorous at rate of $\left(90 \mathrm{~kg} \mathrm{ha}^{-}\right.$ $\left.{ }^{1}\right)$ and potassium at rate of $\left(60 \mathrm{~kg} \mathrm{ha}^{-1}\right)$ were applied to the control treatment while half of nitrogen@60 kg ha ${ }^{-1}$ was applied after seedlings transplantation. After these practices the seedlings of onion cultivars were transplanted in the field.

\section{Experimental design}

The experiment was laid out in Randomized Complete Block Design (RCBD) with split plot arrangement. The treatments were 24 and all treatments replicated three times. The following is the detail of treatments of the experiment (Table 1).

Table 1. Treatments of the experiment

\begin{tabular}{|l|c|c|c|}
\hline \multicolumn{5}{|c|}{ Factor A (Organic manures) $\left(10\right.$ tons ha $\left.{ }^{-1}\right)$} \\
\hline \multicolumn{5}{|c|}{ Main plot } \\
\hline O1 & Control & O5 & $1 / 2 \mathrm{FYM}+1 / 2 \mathrm{PM}$ \\
\hline O2 & Farmyard manure (FYM) & O6 & $1 / 2 \mathrm{FYM}+1 / 2 \mathrm{SMC}$ \\
\hline O3 & Poultry manure (PM) & O7 & $1 / 2 \mathrm{PM}+1 / 2 \mathrm{SMC}$ \\
\hline O4 & Spent mushroom compost (SMC) & O8 & $1 / 3 \mathrm{FYM}+{ }^{1 / 3} \mathrm{PM}+{ }^{1 / 3} \mathrm{SMC}$ \\
\hline \multicolumn{5}{|c|}{ Factor B (Onion cultivars) } \\
\hline \multicolumn{5}{|c|}{ Sub plot } \\
\hline \multicolumn{5}{|c|}{ C2 } & C3 \\
\hline \multicolumn{5}{|c|}{ Swat-1 } \\
\hline
\end{tabular}




\section{Soil analysis}

For soil analysis the soil samples were collected randomly from three different location of experimental field at the depth of $25 \mathrm{~cm}$ before organic fertilizers application, the Physio-chemical analysis was tested in soil department of the Agriculture University of Peshawar.

\section{Variables}

Data was recorded on the following variables.

\section{Survival percentage (\%)}

The data was recorded by counting the plants in each sub-plot of experiment which survived after transplantation by following formula;

Survival percentage $=($ Number of plants survived)/(Total number of transplanted plants) $\times 100$

\section{Number of leaves plant ${ }^{-1}$}

The number of leaves plant ${ }^{-1}$ was noted and means were calculated by selecting five plants randomly from each plot in each replication.

\section{Leaf length (cm)}

The leaf length was measured in centimeters by the help of measuring tape of the leaf by selecting five plants from each plot randomly.

\section{Neck height (cm)}

The neck height was calculated by measuring tape from the bulb top surface to the point where leaves were start to separate of five randomly selected plants from each plot in each replication and the average was calculated.

\section{Plant height (cm)}

The data regarding with plant height was measured in centimeters at the end of the growing seasons that is at harvesting by measuring tape by selecting five plants randomly from each plot in each replication and means were calculated.

\section{Leaf width (cm)}

The leaf width was calculated manually with a ruler of the selected plants from each plot in each replication and the average of leaf width plant $^{-1}$ was calculated.

\section{Statistical Procedure}

The data regarding with different variables were allotted to the statistical variance of analysis to observe the variation between different treatments and also to know the effect of interaction on onion crop. MSTATC (Michigan State University, USA) and Statistical analysis software was used for ANOVA and LSD values [16].

\section{Results and discussion \\ Survival percentage (\%)}

The survival percentage mean data is presented in (Table 2, 3 \& 4), which showed that the organic manures and cultivars had significantly affected the survival percentage while the combination of organic manures and onion cultivars had non significantly affected the survival percentage. The maximum survival percentage $(85.9 \%)$ was noticed in plant which received the organic media (poultry manure) followed by the survival percentage $(84.3 \%)$ applied the organic media (farmyard manure + poultry manure (1:1), while the minimum survival percentage $(72.3 \%)$ was observed in plant with control treatment.. In case of onion cultivars significant variation was recorded among onion cultivars. The maximum survival percentage $(81.9 \%)$ observed in Parachinar-Local closely followed by the swat-1 with survival percentage $(80.2 \%)$ and the minimum survival percentage $(77.9 \%)$ was recorded in swat local cultivar. The results agreed with [17] report that the onion cultivars had significantly affected the survival percentage of plants by using of organic manures.

Addition of organic fertilizers provided more nutrients to the soil and also enhances the water holding capacity. Due to organic fertilizers application well sustainable agriculture achieved because its increased the fertility of soil [18]. From the mean table and analysis of variance reported that the best 
result is obtained by the application of poultry manure by improving the survival percentage on onion cultivars. The related results were presented by [19] that by increasing of fertilizers the survival percentage improved.

\section{Number of leaves plant ${ }^{-1}$}

The data related with number of leaves plant ${ }^{1}$ is presented in (Table 2, $3 \& 4$ ). The organic manures, onion cultivars had significantly affected the number of leaves plant ${ }^{-1}$ of onion cultivars but the interaction had nonsignificantly affected. The organic manures significantly affect the number of leaves plant $^{-1}$ of onion cultivars. The more number of leaves plant ${ }^{-1}$ (16.2) was observed in plant applied organic media (poultry manure) followed by number of leaves plant ${ }^{-1}(11.4)$ in plant received organic media (farmyard manure + poultry manure (1:1). By contrast control treatment showed minimum number of leaves plant ${ }^{-1}$ (8.9).Among onion cultivars the more number of leaves plant ${ }^{-1}$ (12.3) was observed in cultivar (Parachinar-Local), followed by cultivar (Swat-1) with number of leaves per plant (11.4). The less number of leaves plant ${ }^{-1}(10.7)$ was recorded in cultivar (swat local).

Organic manures especially poultry manure gave more nutrients to the plants which increase the vegetative growth of onion plants and thus produce more number of leaves per plants. The research results were supported by [20] who concluded that he organic manures enhanced the vegetative attributes of sweet pepper plants. The nitrogenous organic fertilizers @ 120 kg/ha improved the number of leaves plant ${ }^{-1}$ at early stage, but more application of fertilizers @ $160 \mathrm{~kg} / \mathrm{ha}$ minimized the number of leaves plant $^{-1}[21]$. The same results were also noted in cabbage cultivars that the maximum number of leaves per plants was obtained with the organic manures application [22].

\section{Leaf length (cm)}

The leaf length data is given in (Table 2, 3 \& $4)$. The application of organic manures and onion cultivars had significantly affected the leaf length of onion, whereas the combine response of organic manures and cultivars had non significantly affected. The highest leaf length $(47.6 \mathrm{~cm})$ was recorded in plants received poultry manure, followed by the leaf length $(44.3 \mathrm{~cm})$ in plant received organic media $1 / 2$ farmyard manure $+1 / 2$ poultry manure, whereas the lowest leaf length $(30.3 \mathrm{~cm})$ was observed in plants of control treatment. Among the onion cultivars the maximum leaf length $(40.1 \mathrm{~cm})$ was recorded in Parachinar-Local, followed by leaf length $(38.1 \mathrm{~cm})$ in swat-1.The minimum leaf length $(36.4 \mathrm{~cm})$ was measured in cultivar swatlocal.

The amount of nutrients is more in poultry manure as compare with other organic manures. So the poultry manure gave more nutrients to the plants and these nutrients absorption best and also more increase the growth of the plants. The improvement in the leaf length of onion cultivars it may be due to the genetic variation in the different cultivars of onion. By the application of organic manures gave more nutrients to the plants for the leaf growth. The plants get these nutrients specially the nitrogen which helps in the vegetative growth of the plants. When the plants get these nutrients by applying of organic manures prepared more food for the growth stage, which also help in the leaf development [23]. The results linked with [24] who suggest that the organic manure (poultry manure with vermin compost) enhance the leaf formation more as compare with in organic fertilizers. The leaf length increase might due the fact that the organic manures provide nutrients the soils which recover the $\mathrm{N}$ requirements of plants at developmental stages. Which helps in best soil structure and the nutrients leaching not occur as chemical fertilizers, the plant more 
amount of nutrients which help in leaf formation. Organic manures are nutrients reservoir and by the decomposition of organic manures provide organic acid. The similar results notice by [25] observes that the nutrients (nitrogen @ 150) increased the leaf length in onion crop. The nutrient i.e. Nitrogen is the main components of proteins and the proteins helps in more carbohydrates formation which helps in leaf size [26].

\section{Neck height (cm)}

The mean values of neck height are presented in (Table 2, $3 \& 4$ ) which reported that the organic manures and onion cultivars affect the neck height significantly, whereas the interaction was non-significantly affected. The highest neck height $(7.6 \mathrm{~cm})$ was noted in plant which treated with poultry manure followed by the plants applied organic media $1 / 2$ farmyard manure $+1 / 2$ poultry manure with neck height $(6.7 \mathrm{~cm})$ while the lowest neck height $(4.4 \mathrm{~cm})$ was observed in plants received no organic manure. The maximum neck height $(6.0 \mathrm{~cm})$ was recorded in Parachinar-Local at par with the neck height $(5.6 \mathrm{~cm})$ was measured in cultivar Swat-1. The minimum neck height $(5.3 \mathrm{~cm})$ was noticed in cultivar Swat-Local.

The organic fertilizers enhanced the soil fertility by providing nutrients more than chemical fertilizers. The nitrogen added to the soil by application of organic fertilizers easily accessible to the plants because less problem of leaching occurred, that is a way the plants got large number of nutrients which increased the vegetative growth of plants. The mention results supported with [27] who concluded that by the application of organic manures enhanced the vegetative as well as production of onion crop. [28]Presented the same results that the onion bulb production, structure of soil and more nutrients available to the plants which helped in vegetative growth of plants. Organic manures had important role in the growth of plants and it provided the essential nutrients to the plants for better growth of plants and provided better environment to the human being as compare with chemical fertilizers. The similar results noticed by the [6]. [29] Observed that the onion cultivar (Parachinar-local) gave maximum neck height as compared with the other local cultivars of onion. The application of poultry manure with $\mathrm{N}, \mathrm{P}$ and $\mathrm{K}$ improved the onion plant growth and also enhanced the neck diameter/height of onion crop [30].

\section{Plant height (cm)}

The plant height mean values showed in (Table 5) showed that the organic manures, onion cultivars and their interaction had significantly plant height. The maximum plant height $(79.3 \mathrm{~cm})$ was obtained from the plants applied poultry manure, closely followed by the plant height $(72.3 \mathrm{~cm})$ in plant received organic media $1 / 2$ Farmyard manure $+1 / 2$ poultry manure whereas the minimum plant height $(55.3 \mathrm{~cm})$ was observed in control treatment. The plant height for three different onion cultivars reported that the highest plant height $(69.5 \mathrm{~cm})$ was measured in cultivar Parachinar-Local, followed by plant height $(65.6 \mathrm{~cm})$ in cultivar Swat-1, while the lowest plant height (63.4) was recorded in cultivar Swat-Local. The interaction of organic manures and onion cultivars significantly affected the plant height. In case of interaction the more plant height $(85.5 \mathrm{~cm})$ was observed in Parachinar-Local cultivar received the poultry manure, closely followed by the plant height $(78.2 \mathrm{~cm})$ in Swat-1 cultivar treated with poultry manure. The minimum plant height $(51.4 \mathrm{~cm})$ was noticed in cultivar swat-local with control treatment.

In case of cultivars the difference among the onion cultivars might be due to the adoptability of cultivar to the specific environmental condition and also by the genetic variation of onion cultivars [1]. Similarly [31] studied six onion cultivars in 
which best result was obtained in Swat local and Faisalabad which gave the maximum plant height $(55.0 \mathrm{~cm})$. The organic manures increased the vegetative growth characters significantly the improvement in plant height might be due to supply of more nitrogen and phosphorous by organic manures [32]. The same evaluated by [33] that the organic manures (FYM) helps in enhancing the chemical and physical properties of soil, by its application the condition of soil enhances and more nutrients availability occurred. [3436] also reported that the vegetative growth especially the top growth of carrot increased by organic manures than in organic fertilizers. The plants which received the poultry manure had tallest plant height then the plants which not treated with poultry manure [37]. [38]Reported the poultry along with vermin compost improve the growth and yield parameters of okra. Organic manures showed significant effect on the plant height and number of fruits per plant in chilli crop [39].

\section{Leaf width $(\mathbf{c m})$}

The leaf width was affected significantly by the application of organic manures and onion cultivars while its interaction had nonsignificantly affected the leaf width (Table $5)$. The maximum leaf width $(1.3 \mathrm{~cm})$ was measured in plants which received poultry manure @ 10 tons/ ha, as par as the leaf width $(1.2 \mathrm{~cm})$ was observed in plants which received organic media $1 / 2$ Farmyard manure + $1 / 2$ poultry manure at rate of 10 tons/ha. The minimum leaf width $(0.73 \mathrm{~cm})$ was noticed in plants with control treatment. Onion cultivars had significantly affected leaf width. The cultivar Parachinar-Local showed maximum leaf width $(1.06 \mathrm{~cm})$ as compared with cultivar Swat-1 with leaf width $(0.93 \mathrm{~cm})$, while the minimum leaf width $(0.92 \mathrm{~cm})$ was noted in cultivar Swat-Local.

The onion cultivars Parachinar-Local gave more leaf width as compared with other onion cultivars, may be the reason is that the onion cultivars had different genetic character than other cultivars. The variation occurred in the genetic makeup of the cultivars and also the environmental condition which affect the leaf width of some cultivars and gave less leaf width. Poultry manures improved the leaf width of onion crop, the poultry manures provide more nitrogen to the plants which increased the vegetative growth of the plants and more leaf width observed in the plants. Similar results presented by [40] who noticed that the organic fertilizers affect significantly the leaf width of onion crop as compared with chemical fertilizers. $[24,41]$ reported that the poultry manure along with vermin compost enhanced the leaf growth and leaf area more as compared with inorganic fertilizers in okra and radish.

Table 2. Soil analysis of experimental site at $25 \mathrm{~cm}$ depth

\begin{tabular}{|c|c|c|c|c|c|c|}
\hline \multicolumn{7}{|c|}{ Before transplantation } \\
\hline Determination & Nitrogen (\%) & $\begin{array}{c}\text { Phosphorous } \\
\left(\mathrm{mg} \mathrm{kg}^{-1}\right)\end{array}$ & $\begin{array}{c}\text { Potassium } \\
\left(\mathrm{mg} \mathrm{kg}^{-1}\right)\end{array}$ & $\begin{array}{c}\text { Organic } \\
\text { matter }(\%)\end{array}$ & $\mathrm{pH}$ & $\begin{array}{c}\text { Texture } \\
\text { Class }\end{array}$ \\
\hline Quantity & 0.048 & 8.99 & 111 & 0.81 & 7.5 & $\begin{array}{c}\text { Clay } \\
\text { Loam }\end{array}$ \\
\hline \multicolumn{7}{|c|}{ After harvesting } \\
\hline Control & 0.031 & 6.01 & 90.1 & 0.60 & 7.3 & $\begin{array}{c}\text { Clay } \\
\text { Loam }\end{array}$ \\
\hline $\begin{array}{c}\text { With Organic } \\
\text { Manures }\end{array}$ & 0.062 & 13.6 & 131 & 1.20 & 6.9 & $\begin{array}{c}\text { Clay } \\
\text { Loam }\end{array}$ \\
\hline
\end{tabular}


Table 3. Response of organic manures to survival percentage, number of leaves/plant, leaf length, neck height, plant height and leaf width

\begin{tabular}{|c|c|c|c|c|c|c|}
\hline Organic Manures & $\begin{array}{c}\text { Survival } \\
\text { percentage }\end{array}$ & $\begin{array}{c}\text { No. of } \\
\text { leaves/plant }\end{array}$ & $\begin{array}{c}\text { Leaf } \\
\text { length } \\
(\mathbf{c m})\end{array}$ & $\begin{array}{c}\text { Neck } \\
\text { height } \\
(\mathbf{c m})\end{array}$ & $\begin{array}{c}\text { Plant } \\
\text { height } \\
(\mathbf{c m})\end{array}$ & $\begin{array}{c}\text { Leaf } \\
\text { width } \\
(\mathbf{c m})\end{array}$ \\
\hline Control & $71.89 \mathrm{~g}$ & $7.0 \mathrm{f}$ & $30.3 \mathrm{f}$ & $4.4 \mathrm{e}$ & $55.3 \mathrm{~g}$ & $0.73 \mathrm{e}$ \\
\hline Farmyard manure & $82.55 \mathrm{dc}$ & $13.0 \mathrm{c}$ & $42.2 \mathrm{c}$ & $5.9 \mathrm{c}$ & $69.7 \mathrm{c}$ & $1.0 \mathrm{c}$ \\
\hline poultry manure & $85.95 \mathrm{a}$ & $16.1 \mathrm{a}$ & $47.6 \mathrm{a}$ & $7.6 \mathrm{a}$ & $79.3 \mathrm{a}$ & $1.3 \mathrm{a}$ \\
\hline Spent mushroom compost & $82.02 \mathrm{~d}$ & $11.0 \mathrm{~d}$ & $38.5 \mathrm{~d}$ & $5.1 \mathrm{de}$ & $67.6 \mathrm{~d}$ & $0.8 \mathrm{de}$ \\
\hline $1 / 2 \mathrm{FYM}+1 / 2 \mathrm{PM}$ & $84.25 \mathrm{ab}$ & $14.6 \mathrm{~b}$ & $44.3 \mathrm{~b}$ & $6.7 \mathrm{~b}$ & $72.7 \mathrm{~b}$ & $1.2 \mathrm{~b}$ \\
\hline $1 / 2 \mathrm{FYM}+1 / 2 \mathrm{SMC}$ & $77.78 \mathrm{c}$ & $10.0 \mathrm{de}$ & $34.3 \mathrm{e}$ & $5.1 \mathrm{de}$ & $61.3 \mathrm{ef}$ & $0.9 \mathrm{de}$ \\
\hline $1 / 2 \mathrm{PM}+1 / 2 \mathrm{SMC}$ & $79.95 \mathrm{e}$ & $10.6 \mathrm{~d}$ & $34.6 \mathrm{e}$ & $5.4 \mathrm{~cd}$ & $62.8 \mathrm{e}$ & $0.9 \mathrm{~d}$ \\
\hline $1 / 3 \mathrm{FYM}+1 / 3 \mathrm{PM}+1 /{ }_{3} \mathrm{SMC}$ & $75.02 \mathrm{f}$ & $8.9 \mathrm{e}$ & $33.9 \mathrm{e}$ & $4.9 \mathrm{de}$ & $60.4 \mathrm{f}$ & $0.8 \mathrm{~d}$ \\
\hline $\mathrm{LSD}(5 \%)$ & 1.91 & 1.36 & 1.9399 & 0.7612 & 1.72 & 0.15 \\
\hline
\end{tabular}

Means followed by the same Letter (s) do not differ significantly from one another at $5 \%$ probability level, using LSD test

Table 4. Response of onion cultivars to survival percentage, number of leaves/plant, leaf length, neck height, plant height and leaf width

\begin{tabular}{|c|c|c|c|c|c|c|}
\hline Onion cultivars & $\begin{array}{c}\text { Survival } \\
\text { percentage }\end{array}$ & $\begin{array}{c}\text { Number of } \\
\text { leaves per plant }\end{array}$ & $\begin{array}{c}\text { Leaf } \\
\text { length } \\
\text { (cm) }\end{array}$ & $\begin{array}{c}\text { Neck } \\
\text { height } \\
(\mathbf{c m})\end{array}$ & $\begin{array}{c}\text { Plant } \\
\text { height } \\
(\mathbf{c m})\end{array}$ & $\begin{array}{c}\text { Leaf } \\
\text { width } \\
\text { (cm) }\end{array}$ \\
\hline $\begin{array}{c}\text { Parachinar- } \\
\text { Local }\end{array}$ & $81.88 \mathrm{a}$ & $12.0 \mathrm{a}$ & $40.1 \mathrm{a}$ & $6.0 \mathrm{a}$ & $69.5 \mathrm{a}$ & $1.06 \mathrm{a}$ \\
\hline Swat-1 & $80.98 \mathrm{a}$ & $11.5 \mathrm{ab}$ & $38.1 \mathrm{~b}$ & $5.6 \mathrm{ab}$ & $65.6 \mathrm{~b}$ & $0.93 \mathrm{~b}$ \\
\hline Swat-local & $76.93 \mathrm{~b}$ & $10.7 \mathrm{~b}$ & $36.4 \mathrm{c}$ & $5.3 \mathrm{~b}$ & $63.4 \mathrm{c}$ & $0.92 \mathrm{~b}$ \\
\hline LSD (5\%) & 2.97 & 0.79 & 0.6024 & 0.4217 & 1.08 & 0.08 \\
\hline
\end{tabular}

Means followed by the same Letter (s) do not differ significantly from one another at $5 \%$ probability level, using LSD test

Table 5. Survival percentage, number of leaves/plant, leaf length, neck height, plant height and leaf width as affected by interaction of organic manure and onion cultivars

\begin{tabular}{|c|c|c|c|}
\hline Organic manure & $\begin{array}{c}\text { Parachinar } \\
\text { local }\end{array}$ & Swat 1 & Swat local \\
\hline Control & 59.2 & 55.2 & 51.4 \\
\hline Farmyard manure & 71.5 & 70.4 & 67.2 \\
\hline poultry manure & 85.5 & 78.2 & 74.2 \\
\hline Spent mushroom compost & 70.5 & 66.8 & 65.3 \\
\hline $1 / 2$ FYM + 1/2PM & 76.1 & 71.7 & 70.3 \\
\hline $1 / 2$ FYM + 1/2SMC & 63.9 & 60.6 & 59.4 \\
\hline $1 / 2 \mathbf{P M}+1 / 2 \mathrm{SMC}$ & 67.5 & 61.6 & 59.3 \\
\hline $1 / 3 \mathrm{FYM}+1 / 3 \mathrm{PM}+1 / 3 \mathrm{SMC}$ & 61.5 & 60.2 & 59.6 \\
\hline
\end{tabular}

LSD value for organic manures $x$ time of application at 5\% level of Probability $=3.04$

\section{Conclusion and recommendations}

From the result it is concluded that the application of organic manures and onion cultivars significantly affected the growth of onion. Poultry manure improved the survival percentage, number of leaves plant-1, leaf 
length $(\mathrm{cm})$, leaf width $(\mathrm{cm})$, neck height $(\mathrm{cm})$ and plant height $(\mathrm{cm})$ of onion cultivars while Parachinar-Local cultivar respond positively to survival percentage, number of leaves plant-1, leaf length $(\mathrm{cm})$, leaf width $(\mathrm{cm})$, neck height $(\mathrm{cm})$ and plant height $(\mathrm{cm})$. So the application of 10 tons ha-1 of poultry manure about 1 month before transplantation of seedlings along with cultivar "ParachinarLocal" is recommended for better growth of onion crop in agro-climatic condition of Peshawar.

\section{Authors' contributions}

Conceived and designed the experiments: $M$ Ali \& G Ayub, Performed the experiments: M Ali, MW Khan \& A Naeem, Analyzed the data: M Ali, K Khan, S Rehman \& M Rehman, Contributed materials/ analysis/ tools: M Afzaal, R Ullah \& M Ali, Wrote the paper: N Khan \& M Ali.

\section{References}

1. Khan IM, Hassan G, Khan I \& Marwat KB (2011). Testing of herbicides at various doses on the growth stages of wild onion grown in pots. Sarhad J Agric 27(1): 85-91.

2. Baloch AF (1994). Vegetable crops. Horticulture. National Book Foundation. Islamabad, Pakistan, pp 489-537.

3. Malik MN (1994). Bulb crops, Onion. Horticulture. National Book Foundation Islamabad Pakistan, pp 500-501.

4. MINFA (2013). Department of Agriculture Statistics Government of Khyber Pakhtunkhwa, Pakistan

5. Young JE, Zhao X, Carey EE, Welti R, Yang SS \& Wang W (2005). Phytochemical phenolics in organically grown vegetables. Mol Nutri and Food Res 49(12): 1136-1142.

6. Aisha AH, Rizk FA, Shaheen AM \& Abdel-Mouty MMM (2007). Onion plant growth, bulbs yield and its physical and chemical properties as affected by organic and natural fertilization. Res $J$ Agri and Biol Sci 3(5): 380-388.

7. Naeem M, Iqbal J \& Bakhsh MAA (2006). Comparative study of inorganic fertilizers and organic manures on yield and yield components of mungbean (Vigna radiateL.). J of Agri and Social Sci 2: 227-229.

8. Babajide PA, Olabode OS, Akanbi WB, Olatunji OO \& Ewetola EA (2008). Influence of composted Tithoniabiomass and $\mathrm{N}$-mineral fertilizer on soil physico-chemical properties and performance of tomato (Lycopersican lycopersicum). Res J of Agronomy 2(4): 101-106.

9. Bradley S (2004). Vegetable gardening, growing and harvesting vegetables. Murdoch Book. ISBN: 1-74045-519-3.

10. Jayathilake PKS, Reddy IP, Srihari D\& Reddy KR (2006). Productivity and soil fertility status as influenced by integrated use of n-fixing biofertilizers, organic manures and inorganic fertilizers in onion. J of Agric Sci 2(1): 46-58.

11. Maheswarappa HP, Nanjappa HV, Hegde MR \& Balu SR (1999). Influence of planting material, plant population and organic manures on yield of East Indian Galangal and on soil physiochemical and biological properties

12. Bhuma M (2001)). Studies on the impact of humic acid on sustenance of soil fertility and productivity of green gram. MSc (Ag) Thesis. TNAU. Coimbatore.

13. Carol M, Tanya C \& Tamera F (1999)). A Manure Resource Guide for farmers and gardeners in western Washington. 
King Conservation District 935 Powell Ave SW Renton. WA 98055. 206.

14. Shaheen A, Fatma M, Rizk A \& Singer SM (2007). Growing Onion Plants without Chemical Fertilization. Res $J$ Agri Biol Sci 3(2): 95-104.

15. Colla G, Mitchel J, Poudel D \& Temple S (2002). Changes of tomato yield and fruit elemental composition in conventional low input and organic systems. J of Sus Agri 20(2): 53-67.

16. Steel RG \& Torrie JH (1980). Analysis of covariance, In: Principles and Procedures of Statistics: a Biometrical Approach, SMC Graw-Hill, New York, pp 401-437.

17. Sajid M, Rub A, Shah ST, Jan I, Huq I, Haleema B, Zamin M, Alam R \& and Zada H ( 2012). humic acids effect on bulb production of onion cultivars. Afr $J$ Microbiol Res 6(28): 5769-5776.

18. Subbarao TS \& Shankar CR (2001). Effect of organic manures on growth and yield of brinjal. South Ind Hort 49: 288291.

19. Ghafoor A, Jilani MS, Khaliq G \& Waseem K (2003). Effect of different NPK levels on the growth and yield of three onion (Allium cepaL.) cultivars. Asian J Plant Sci 2(3): 342-346.

20. Shams ASA (2003). Response of sweet pepper crop to organic and biofertilizer application. M.Sc Thesis Fac Agric Moshtohor, Zagazig Uni Egypt, pp 148.

21. Nasreen S, Haque MM, Hossain MA \& Farid ATM ((2007). Nutrient uptake and yield of onion as influenced by nitrogen and sulphur fertilization. Bang J Agri Res 32(3): 413-420.
22. Sharma HK, Prasad D, Pankaj \& Sharma $P$ (2006). Bio-management of Meloidogyne incognita infesting okra, pp 14(1): 191:193.

23. Flore JA \& Layne DR (1999). Photo assimilate production and distribution in Cherry. Hort Sci 34(6): 1015-1019.

24. Dhananjaya (2007). Organic studies in radish (RaphanussativusL.) varieties. M.Sc. (Hort). Thesis, Department of Horticulture, College of Agriculture, Dharwad Uni of Agri Sci, Dharwad, pp 580.

25. Singh J \& Chaure NK (1999). Effect of age of seedlings and nitrogen levels on growth and yield of onion (Allium cepaI L.). Adv Hortic 6: 73-77.

26. Bungard, RA, Wingler A, Morton JD \& Andrews M (1999). Ammonium can stimulate nitrate and nitrite reductase in the absence of nitrate in Clematis vitalba. Plant Cell Envi 22: 859-866.

27. Shahriazzaman MC, Mazed HEMK, Pulok MAI, Mehraj H \& Uddin AFM (2014). Response of organic manures on growth and yield of okra (Abelmoschusesculentus L.). $\quad J \quad S c i$ Techniol Environ 1(2): 60-67.

28. Faten SAE, Ahmed AA \& Abdel-Baky MHH (2002). Growth, yield and nutritional value of square as affected by town refuse manure and sulphur addition. Egypt J Appl Sci 17: 716-735.

29. Shah ST, Sajid M, Alam R, Rab A, Mateen A, Jan I, Ali A \& Wahid F (2012). Comparative study of onion cultivars at Mardan, Khyber Pakhtunkhwa - Pakistan. Sarhad J Agri 28(3): 399-402. 
30. Abdel-mohamed MM, El-mazny MY, Abdel-mageed YT, moustsfa YM \& Yamani SS (2015). Role of some organic and inorganic fertilizers on productivity and storage ability of egyption onion grown in sandy soil. International conference for agriculture and irrigation in the nile basin countries.

31. Majeed A (1986). Verietal trail on onion. Annual rept Agri Sta Mingora, pp 11-14.

32. Makwunye AU (1977). Effect of three phosphorous Sources on available cation content of soil. Samaru. Samaru J of Agri $\operatorname{Res}(2)$ : 103 - 109.

33. Ajakaiye MB (1971). Organic manure on vegetations. Samaru Agric Newsletter 13(1): 9 -10.

34. Dennison EO (1961). The Value of FYM in maintaining soil fertility in Northern Nigeria. Empire J of Exp Agri 39: 350 356.

35. Austin AK, Chris JB \& Harley US (1963). Effect of FYM on growth and yield of carrot. J of Hort Sci 38: 22 - 26.

36. Mazur T \& Gronowicz Z (1974). Nitrogen fertilization of fodder carrot, Field crop abstract. 28.
37. Pavan Y, Singh P, Yadav RL \& Ram L (2004). Organic manures and nitrogen levels on okra. Haryana. J Hort Sci 33(1/2): 124-126.

38. Prakash YS \& Bhadoria PBS (2004). Relative efficacy of different organic manures on the performance of okra (Abel moschus esculentus L.) grown in Lateritic soil. Tropic Agri 81(4): 197203.

39. Dileep SN (2005). Studies on effect of organic manures on the productivity and quality of chilli CV K1. MSC (Hort). Thesis TNAU Cbe.

40. Suresh D, Goyal S, Kapoor K \& Mundra M (2004). Microbial biomass carbon and microbial activities of soils receiving chemical fertilizers and organic amendments. Archives Agron Soil Sci 50: 641-647

41. Prabu T, Narwadkar PR, Sanindranath AK \& Rafi M (2003).Effect of integrated nutrient management on growth and yield of okra (Abelmoschus esculentusL. Moench) cv. Parbhani Kranti. Orissa J Horti (31): 17-21. 